\title{
EMISSIONS BENEFITS OF DISTRIBUTED GENERATION IN THE TEXAS MARKET
}

\section{April 2003}

Prepared by

S. W. Hadley

J. W. Van Dyke 


\title{
DOCUMENT AVAILABILITY
}

Reports produced after January 1, 1996, are generally available free via the U.S. Department of Energy (DOE) Information Bridge:

Web site: http://www.osti.gov/bridge

Reports produced before January 1, 1996, may be purchased by members of the public from the following source:

\author{
National Technical Information Service \\ 5285 Port Royal Road \\ Springfield, VA 22161 \\ Telephone: 703-605-6000 (1-800-553-6847) \\ TDD: $703-487-4639$ \\ Fax: 703-605-6900 \\ E-mail: info@ntis.fedworld.gov \\ Web site: http://www.ntis.gov/support/ordernowabout.htm
}

Reports are available to DOE employees, DOE contractors, Energy Technology Data Exchange (ETDE) representatives, and International Nuclear Information System (INIS) representatives from the following source:

Office of Scientific and Technical Information

P.O. Box 62

Oak Ridge, TN 37831

Telephone: 865-576-8401

Fax: 865-576-5728

E-mail: reports@adonis.osti.gov

Web site: http://www.osti.gov/contact.html

\begin{abstract}
This report was prepared as an account of work sponsored by an agency of the United States Government. Neither the United States government nor any agency thereof, nor any of their employees, makes any warranty, express or implied, or assumes any legal liability or responsibility for the accuracy, completeness, or usefulness of any information, apparatus, product, or process disclosed, or represents that its use would not infringe privately owned rights. Reference herein to any specific commercial product, process, or service by trade name, trademark, manufacturer, or otherwise, does not necessarily constitute or imply its endorsement, recommendation, or favoring by the United States Government or any agency thereof. The views and opinions of authors expressed herein do not necessarily state or reflect those of the United States Government or any agency thereof.
\end{abstract}




\section{EMISSIONS BENEFITS OF DISTRIBUTED GENERATION IN THE TEXAS MARKET}

S. W. Hadley

J. W. Van Dyke

April 2003

For the

Gas Technology Institute

OAK RIDGE NATIONAL LABORATORY

Oak Ridge, Tennessee 37831

managed by

UT-BATTELLE, LLC

for the

U.S. DEPARTMENT OF ENERGY

under contract No. DE-AC05-00OR22725 


\section{CONTENTS}

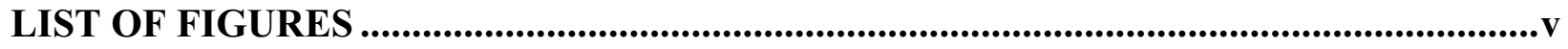

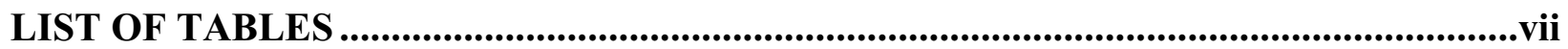

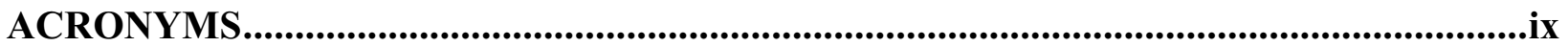

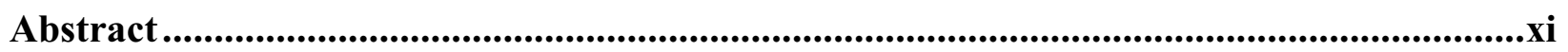

1. Introduction and background........................................................................

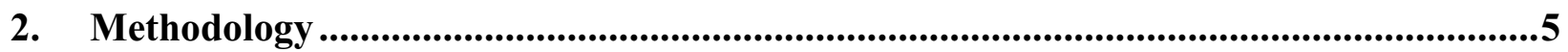

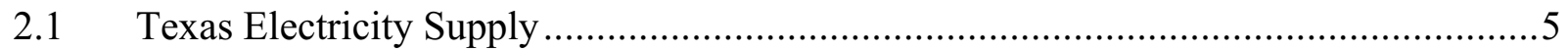

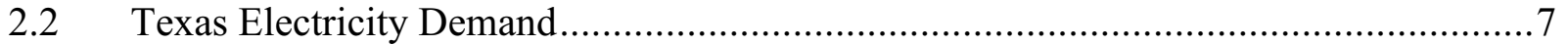

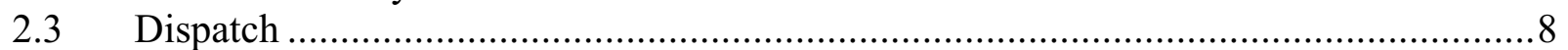

2.4 Distributed Generation............................................................................... 10

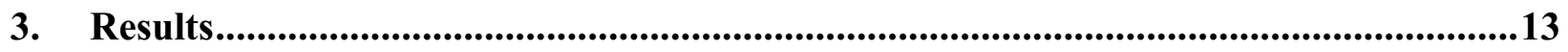

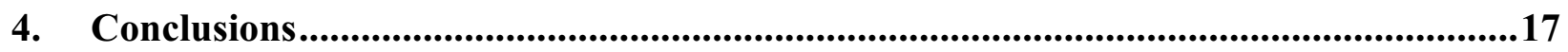

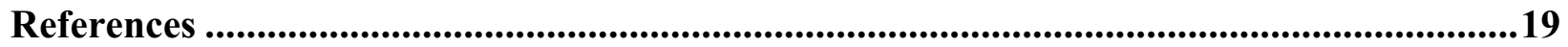




\section{LIST OF FIGURES}

Figure 1. Power plants operating when demand is high or low .......................................... 1

Figure 2. Electric Reliability Council of Texas Control Area.............................................2

Figure 3. ERCOT hourly system demand for 2012 (1999 values times 1.294$)$........................7

Figure 4. Load Duration Curves for ERCOT in 2012 ..................................................... 8

Figure 5. Peak season dispatch of plants to meet load in order of increasing variable cost. ......... 9

Figure 6. Net $\mathrm{CO}_{2}$ and $\mathrm{NO}_{\mathrm{x}}$ emissions from $100 \mathrm{MW}$ of Combustion Turbine-8J w/o CHP....... 14

Figure 7. System $\mathrm{NO}_{\mathrm{X}}$ savings as a function of the $\mathrm{DG} \mathrm{NO}_{\mathrm{X}}$ emissions rate ............................15

Figure 8. Net $\mathrm{CO}_{2}$ and $\mathrm{NO}_{\mathrm{x}}$ emissions from $100 \mathrm{MW}$ of Combustion Turbine-8J with 50\% CHP 


\section{LIST OF TABLES}

Table 1. ERCOT 2012 Base Case capacity and emissions ..................................................5

Table 2. Distributed Generation Technologies................................................................. 10

Table 3. Heat exchanger efficiencies of CHP technologies ............................................ 11

Table 4. Key parameters of displaced system power...................................................... 13

Table 5. Net $\mathrm{CO}_{2}$ and $\mathrm{NO}_{\mathrm{x}}$ emissions from $100 \mathrm{MW}$ of Combustion Turbine-8J with and without

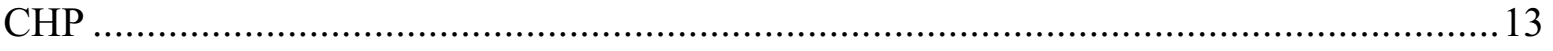

Table 6. Net emissions from $100 \mathrm{MW}$ of different DG technologies w/o CHP ........................14

Table 7. Net emissions from $100 \mathrm{MW}$ of different DG technologies with 50\% of DG being CHP 


\section{ACRONYMS}

$\begin{array}{ll}\text { AEO2002 } & \text { Annual Energy Outlook 2003 } \\ \text { CC } & \text { Combined Cycle } \\ \mathrm{CO}_{2} & \text { Carbon dioxide } \\ \text { CT } & \text { Combustion Turbine } \\ \text { CHP } & \text { Combined Heat and Power } \\ \text { DG } & \text { Distributed Generation } \\ \text { DOE } & \text { Department of Energy } \\ \text { EIA } & \text { Energy Information Administration } \\ \text { ERCOT } & \text { Electric Reliability Council of Texas } \\ \text { GBtu } & \text { Giga (Billion) British Thermal Units } \\ \text { GW } & \text { GigaWatt } \\ \text { GWh } & \text { GigaWatt-hours } \\ \text { LDC } & \text { Load Duration Curve } \\ \text { MW } & \text { MegaWatt } \\ \text { MWh } & \text { MegaWatt-hours } \\ \text { NEMS } & \text { National Energy Modeling System } \\ \text { NOX } & \text { Nitrogen oxides } \\ \text { ORCED } & \text { Oak Ridge Competitive Electricity Dispatch model } \\ \text { ORNL } & \text { Oak Ridge National Laboratory } \\ \text { ST } & \text { Steam Turbine } \\ \text { TBtu } & \text { Trillion British Thermal Units } \\ \end{array}$




\begin{abstract}
One potential benefit of distributed generation (DG) is a net reduction in air emissions. While DG will produce emissions, most notably carbon dioxide and nitrogen oxides, the power it displaces might have produced more. This study used a system dispatch model developed at Oak Ridge National Laboratory to simulate the 2012 Texas power market with and without DG. This study compares the reduction in system emissions to the emissions from the DG to determine the net savings.

Some of the major findings are that $85 \%$ of the electricity displaced by DG during peak hours will be simple cycle natural gas, either steam or combustion turbine. Even with DG running as baseload, $57 \%$ of electricity displaced will be simple cycle natural gas. Despite the retirement of some gas-fired steam units and the construction of many new gas turbine and combined cycle units, the marginal emissions from the system remain quite high $(1.4 \mathrm{lb} \mathrm{NO} / \mathrm{MWh}$ on peak and $1.1 \mathrm{lb} \mathrm{NO} / \mathrm{MWh}$ baseload) compared to projected DG emissions. Consequently, additions of DG capacity will reduce emissions in Texas from power generation in 2012. Using the DG exhaust heat for combined heat and power provides an even greater benefit, since it eliminates further boiler emissions while adding none over what would be produced while generating electricity. Further studies are warranted concerning the robustness of the result with changes in fuel prices, demands, and mixes of power generating technology.
\end{abstract}




\section{EMISSIONS BENEFITS OF DISTRIBUTED GENERATION IN THE TEXAS MARKET}

\section{INTRODUCTION AND BACKGROUND}

One potential benefit of distributed generation (DG) is a net reduction in air emissions. While DG will produce emissions, most notably carbon dioxide and nitrogen oxides, the power it displaces might have produced more. However, while the emissions from DG are easily quantified, the reductions in emissions from displaced power production are more difficult to determine. They depend upon which power plants would have produced the power. If the DG displaces new, clean power sources, then the project may not reduce overall emissions. However, if DG displaces power from older and dirtier plants, then it is likely there will be a net reduction in overall emissions.

Power demands on the grid are always changing and the marginal, or last, plant used to provide that last bit of power changes as well. When DG displaces power demand on the grid, it does not displace one plant for the whole time, but rather whichever plants happen to be on the margin over the given time. During low demand times, it may displace lower cost gas plants or even coal or nuclear plants in some regions of the country (Figure 1). At peak times, it may displace highcost gas combustion turbines, steam plants, or even oil-fired plants.

In order to determine the set of plants that change their production it is necessary to model the dispatching of power plants at different levels of system demand, with and without DG. Changes in total plant emissions can then be compared to the DG emissions to determine the net impact.

DG projects can also have the benefit of providing waste heat for industrial processes or other needs. This thermal source, normally waste heat simply released to the environment from centralized generating units, can displace energy produced by boilers on-site and thereby displace the emissions that those boilers would have created. Since the emissions from the DG would occur anyway in the production of electricity, the reduction from displaced boiler production can give substantial additional emission

Figure 1. Power plants operating when demand is high or low

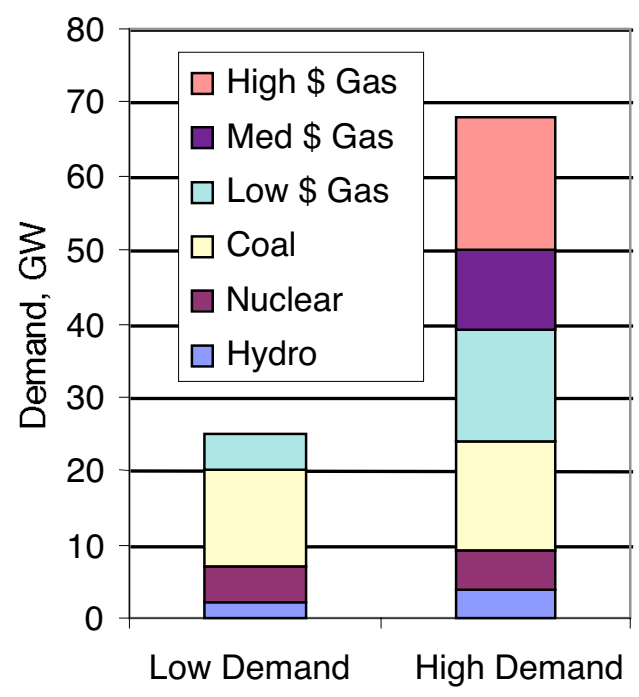
benefits.

While DG capacity additions may displace emissions from other plants, regulatory agencies have not used the displacement as a basis in their regulations. The difficulty in assessing the amount of displacement, because of its dependence on the multitude of other decisions concerning other plants beyond the control of the DG owner, makes determining a consistent value difficult. Rather, new capacity has been treated as an addition to overall emissions and the changes to 
other operations not included. Standards are defined in terms of "Best Available Control Standard (BACT)" and "Lowest Achievable Emission Rate (LAER)" to reflect that cleaner plants are always desirable. Texas is considering giving credit for the thermal energy displaced by combined heat and power (CHP). This amount is more easily measured because it is not based on the emissions from the electric system as a whole but rather the specific source of thermal energy for the site where the DG is located.

If the DG capacity is added in conjunction with new electricity demand, as opposed to a retrofit in existing facilities, then it is more difficult to establish that the DG actually displaces other production. Because of the resulting variability in net emissions for the same equipment but in different locations or time frames, it would be difficult to utilize the net emission calculation within a regulatory framework. Nevertheless, displacement of emissions can occur and significantly alter the actual impact of DG capacity on air quality.

The purpose of this study is to calculate the net emissions savings from implementing a DG technology in Texas, notably the reliability region for Texas called the Electric Reliability Council of Texas (ERCOT) (Figure 2). This region is a relatively self-contained electric power system and covers most of the population of Texas.

Figure 2. Electric Reliability Council of Texas Control Area

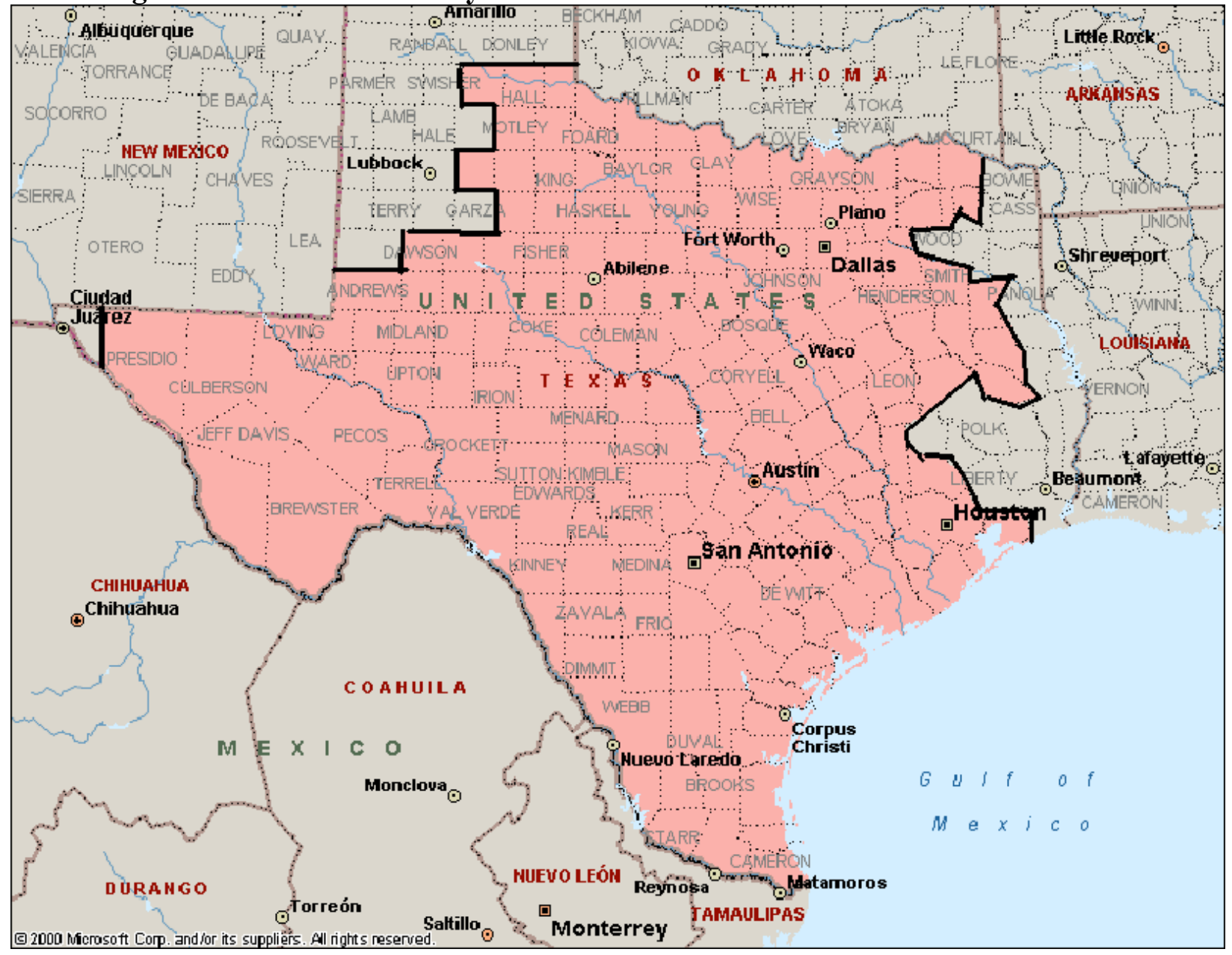

Source ERCOT 
Two main scenarios were considered: one with DG used mainly during peak times and the other with DG providing constant power. Various DG technologies were examined, and the use of the waste heat for CHP was considered. The year of interest for the study was 2012. The expected demands, set of power plants, and available DG technologies for 2012 were determined from available databases and literature. The ORCED (Oak Ridge Competitive Electricity Dispatch) model was used to simulate the electricity market.

The general steps were as follows. First, the power demands and set of power plants were established for a baseline scenario. Then, $100 \mathrm{MW}$ of distributed generation was introduced, with a concomitant reduction in demands on the rest of the system. Some power plants within the state were called on less frequently, thereby reducing emissions. The emissions from the DG itself were calculated, and alternative assumptions were made about waste heat used for CHP. Then the reduced emissions from boilers were calculated. Finally, the net changes in emissions of each scenario show the overall impact of the DG technology. Section 2 describes this process in more detail. Section 3 describes the results, and Section 4 gives the conclusions. 


\section{METHODOLOGY}

In order to determine what plants will be displaced by DG production, we must determine the baseline supply and demand for the region. We then convert the supply and demand into the form used by the ORCED model. We next create alternative demand scenarios with DG displacing some of the system demand. Taking the difference in results between ORCED cases with and without the assumed DG, we find the amount of change on the margin due to the DG production. Adding in the DG emissions, and subtracting any displaced emissions from any of the thermal energy assumed to be used in CHP, we can find the net emissions.

\subsection{TEXAS ELECTRICITY SUPPLY}

The first step is to determine the supply for electricity in the ERCOT region for 2012, including the operating and emissions characteristics. The main list of plants comes from the database used by the Energy Information Administration (EIA) for their National Energy Modeling System (NEMS). In December 2001, the EIA issued the Annual Energy Outlook 2002 (AEO2002) report (EIA 2001) that forecasts demands to 2020 for various regions of the country. One of the input files to this model is a listing of over 19,000 power plant units across the country and includes capacity, heat rates, emissions, date of construction and retirement, among other characteristics. The power plants in the ERCOT region that will be operating in 2012 can be pulled from this database. This results in a list of 666 units with a combined capacity to the electric power grid of $59,000 \mathrm{MW}$. Over 5,300 MW in the database are scheduled for retirement between 2000 and $2012,91 \%$ of it gas-fired steam units. The database also shows planned expansions of 6,560 MW: 46\% gas-fired combined cycle (CC), 33\% renewable, and 20\% combustion turbine (CT).

The NEMS model calculates the amount of additional generation needed for the region over and above those planned expansions and simulates the construction of different types of plants to fill this gap. We added 11,000 MW of combined cycle gas turbine and 7,000 MW of gas-fired combustion turbines to represent the addition that the AEO 2002 projects. Table 1 shows the total amount of capacity for the system by plant type and the average emission rate (for new and old plants combined). These amounts only show the capacity that actually sell power on the grid. There is at least $4 \mathrm{GW}$ of additional CC capacity plus other technologies that is used internally by cogenerators and not included in these numbers.

Table 1. ERCOT 2012 Base Case capacity and emissions

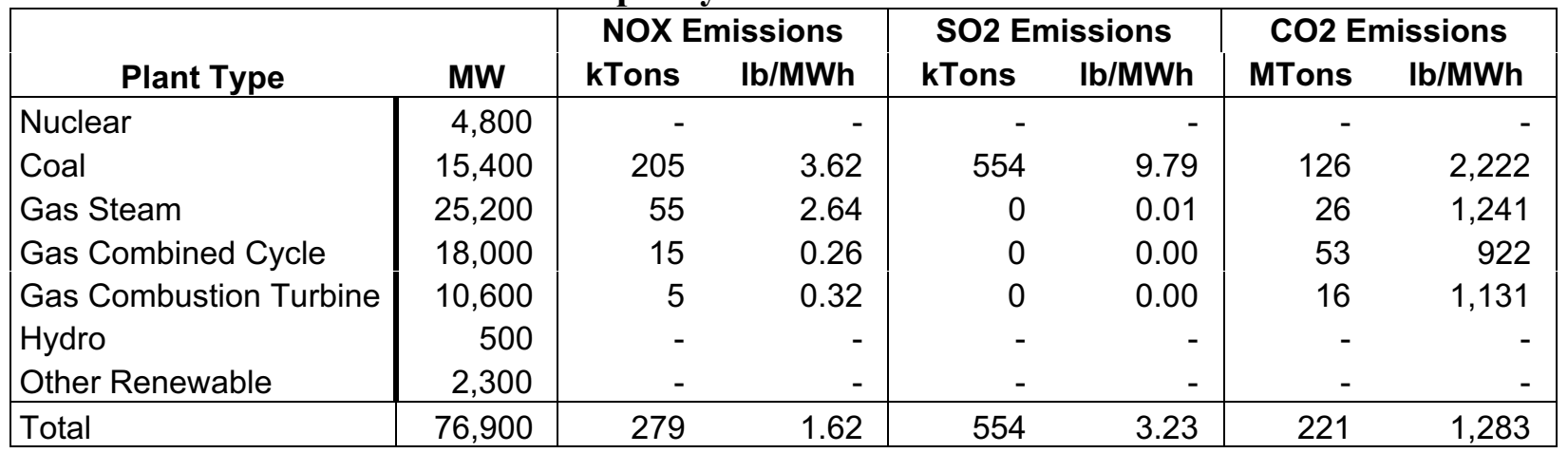


The EIA database does not include fuel costs for the power plants since these are calculated internally in NEMS. However, EIA publishes separate reports that give historical data on fuel costs by state and region (EIA 2000b). These can be applied to plants based on the type of fuel they use. In addition, we used data from the PowerDAT database available from Platts (Platts 2002). This database contains a wealth of information, including costs and production for most of the power plants across the country. Platts collects this information from various forms that utilities submit to the Federal Energy Regulatory Commission, EIA, and state regulatory agencies.

While the EIA database does include values for $\mathrm{NO}_{\mathrm{x}}$ emissions, more accurate values are available from the Environmental Protection Agency's E-GRID database (EPA 2001). The most recent data that they have published is from 1998. The E-GRID data was consolidated with the EIA and PowerDAT data to create a comprehensive list of power plants with their operation and the emission parameters. For all of the future plants, we used the standard that the Texas Natural Resources Conservation Commission has set for new plants operating $>300$ hours in East Texas constructed after 2005, $0.14 \mathrm{lb} \mathrm{NO} / \mathrm{MWh}$ (TNRCC 2001). These emission standards do not apply to existing plants. Emissions from coal-fired power plants do not impact the results since no coal production was displaced by DG. Due to the significant amount of natural gas-fired generation in Texas gas plants were always the marginal production. As a result, pending policy changes that will reduce emissions from coal-fired power plants will not affect this analysis.

Existing plants may reduce their emission rates due to further regulations, especially those in EPA non-attainment areas. Differentiation of plants by location within Texas, and more recent data on emissions post-2000 would be helpful. Further analysis on sensitivities of the results with changes in existing plant levels may be worthwhile.

The ORCED model described below can simulate the dispatch of up to 200 plants over a yearlong period. Therefore, it was necessary to aggregate the 667 plants into this smaller set, combining plants with similar characteristics and costs. In addition, fuel costs in the PowerDAT and EIA databases that we used were from 1999. (Fuel costs in 2000 and 2001 were very unusual, with extraordinarily high gas prices for portions of the year, so were not used. Our results on emissions would not be much different if we had used later data since the DG only displaced gas-fired generation.) To simulate the costs in 2012, we determined the expected amount of growth in fuel prices for the region in the AEO2002 and applied these to each plant's fuel cost.

We included in the variable costs for each plant allowance charges for their $\mathrm{SO}_{2}$ and $\mathrm{NO}_{\mathrm{X}}$ emissions. The prices of emissions allowances depend on the type of market that will exist in 2012 and the regulations on the specific emissions and co-emissions of other pollutants, as discussed in detail in the AEO2002 (EIA 2001). We used a value of $\$ 200 /$ ton of $\mathrm{SO}_{2}$ based on the AEO2002 results, and $\$ 1500 /$ ton $\mathrm{NO}_{\mathrm{X}}$, based on work done for the Southern Appalachian Mountain Initiative Final Technical Report (SAMI August 2002, draft). The $\mathrm{NO}_{\mathrm{X}}$ price is only charged during the summer months between May 1 and September 30, in line with EPA regulations to combat ozone formation. Since this study was only concerned with emission changes the main impact of these emission prices was to make dirtier plants operate for a lower percentage of time than otherwise. 


\subsection{TEXAS ELECTRICITY DEMAND}

The other key factor in determining power plant production is defining the demands on the grid. All the control areas in the ERCOT region report their hourly electrical load to FERC as part of their Form 714 report. ERCOT makes these data available for several years on their website (ERCOT 2002). Because much of our supply data uses a 1999 base year, we selected that year's hourly demand data. The AEO2002 shows an expected $29.4 \%$ increase in electricity sales between 1999 and 2012, so we simply multiplied each hour's demand by this amount to simulate the demand in 2012. Figure 3 shows the hourly change in demands over the year. Note that the highest demands occur in the summertime, due to the air conditioning requirements.

The ORCED model dispatches power plants in two seasons: peak and off-peak. We selected a peak season between May 1 and September 30 because $\mathrm{NO}_{\mathrm{X}}$ emissions are more heavily regulated in parts of the country during this time. Using this definition allows us to gather more detailed information specific to that season. The two seasons are treated slightly differently within ORCED. In the peak season, no outages are planned and the only outages that happen are random forced outages. In the off-peak season, power plant capacities are derated to represent the portion of time they have planned outages, in addition to having forced outages.

Figure 3. ERCOT hourly system demand for 2012 (1999 values times 1.294)

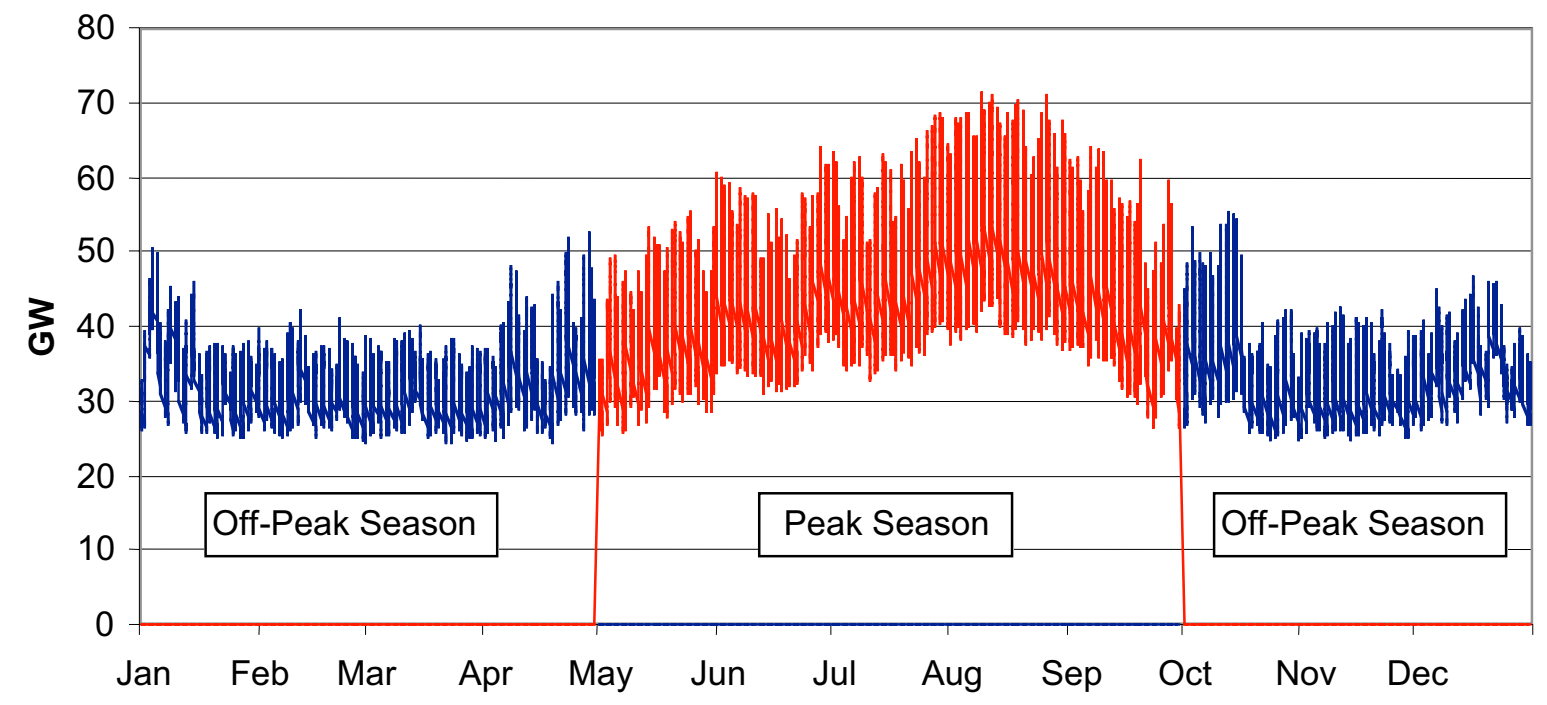

The power loads from all of the hours of each season are stacked in increasing order to create the load duration curve (LDC) for each season (Figure 4). The curves show the percentage of time that demand was at least a given power level. For example, during the peak season, demand was $26,000 \mathrm{MW}$ or greater $100 \%$ of the time. For $50 \%$ of the season, demand was $45,000 \mathrm{MW}$ or greater, and for $10 \%$ of the season, demand was $60,000 \mathrm{MW}$ or greater. The off-peak season has a lower, flatter curve than the peak season because of the lack of air-conditioning loads that drive the peak during the summer months. Combined, the two curves create the annual LDC. Since ORCED uses a three-segment line to represent each LDC, we fit line segments to match the curves. These are shown in the figure as well. 
As DG is used to displace system demand, the load shapes change and the LDC's need to be recalculated. For this study, we considered two DG deployment options: a weekday only system that ran from $8 \mathrm{am}$ to $8 \mathrm{pm}$ (henceforth called Peaking DG), and a system that ran $100 \%$ of the time (called Baseload DG). We added only $100 \mathrm{MW}$ of DG, large enough that it would be differentiable on the LDC, yet small enough that we could avoid making changes to the system capacity by retiring additional plants or not building some new capacity. This gave a picture of which plants would be called upon less often due to the DG, without having to prejudge which capacity would be reduced.

Figure 4. Load Duration Curves for ERCOT in 2012

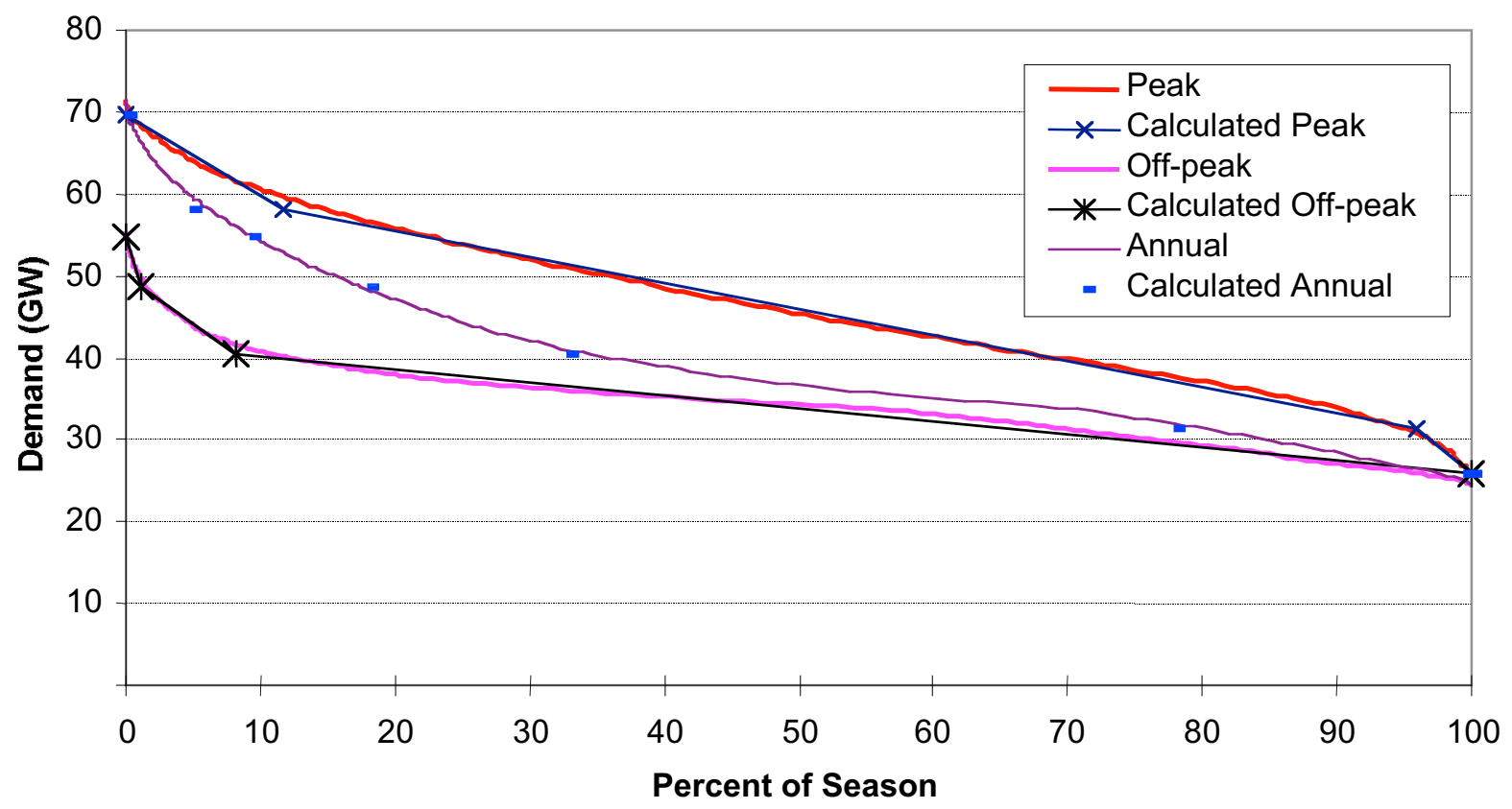

\subsection{DISPATCH}

Once supply and demand for a system was defined, the supply could be dispatched to meet the demand for the period. Once plants were dispatched, their production, costs, emissions, and other factors could be determined. To do this, we used the ORCED model. It was developed at Oak Ridge National Laboratory to examine numerous facets of a restructured electricity market (Hadley and Hirst 1998). ORCED deals just with generation for a region but calculates a number of key financial and operating parameters. The ORCED model has been used in a variety of studies by different groups across the country including:

- $\quad$ Market incentives for adequate generation capacity in a restructured electricity market

- Impact of restructuring on power prices in the Pacific Northwest

- $\quad$ Stranded cost recovery processes in the mid-Atlantic region

- Effect of NOx emission control implementation plans on system reliability 
- Potential for economic biomass cofiring on a state and regional basis

- $\quad$ National carbon emissions under differing energy and carbon reducing scenarios

- $\quad$ Effect of carbon taxes on power production in the Midwest

- $\quad$ Benefits of multiple emission controls strategies

- Impacts of hydropower relicensing on carbon emissions

- Impacts of restructuring on prices and transmission in Oklahoma

The model takes the inputs on supply and demand described above and dispatches plants to meet the defined demands for a single year of operation. Several versions of the model have been developed over the years depending on the needs of the study. For this study, we used a version that models a single region without internal transmission constraints. It can handle up to 200 power plants and models two seasons, a peak and an off-peak.

For each season, the power plants are arranged in order of increasing variable costs, representing the prices they would bid into the market (Figure 5). One exception to the rule is nondispatchable plants such as cogenerators. They are forced to the bottom of the order with their capacity derated to represent the total energy supplied based on their availability, according to the EIA data. Nuclear plants are usually next because of their typically low variable costs, followed by low-cost coal plants. As variable costs increase, there will be a mix of gas-fired plant types (steam-ST, combustion turbine-CT, and combined cycle-CC) depending on the individual plants' efficiencies and gas prices. Of the natural gas-fired plants, combined cycle plants are generally the most efficient and cheapest to run. In Figure 5 we show a dividing line at $40 \mathrm{GW}$ where most of the combined cycle plants have lower cost and provide the majority of the energy. Above this line, most of the capacity is from gas-fired ST and CT.

Figure 5. Peak season dispatch of plants to meet load in order of increasing variable cost. Percentages represent the fraction of energy provided by that plant type in each block.

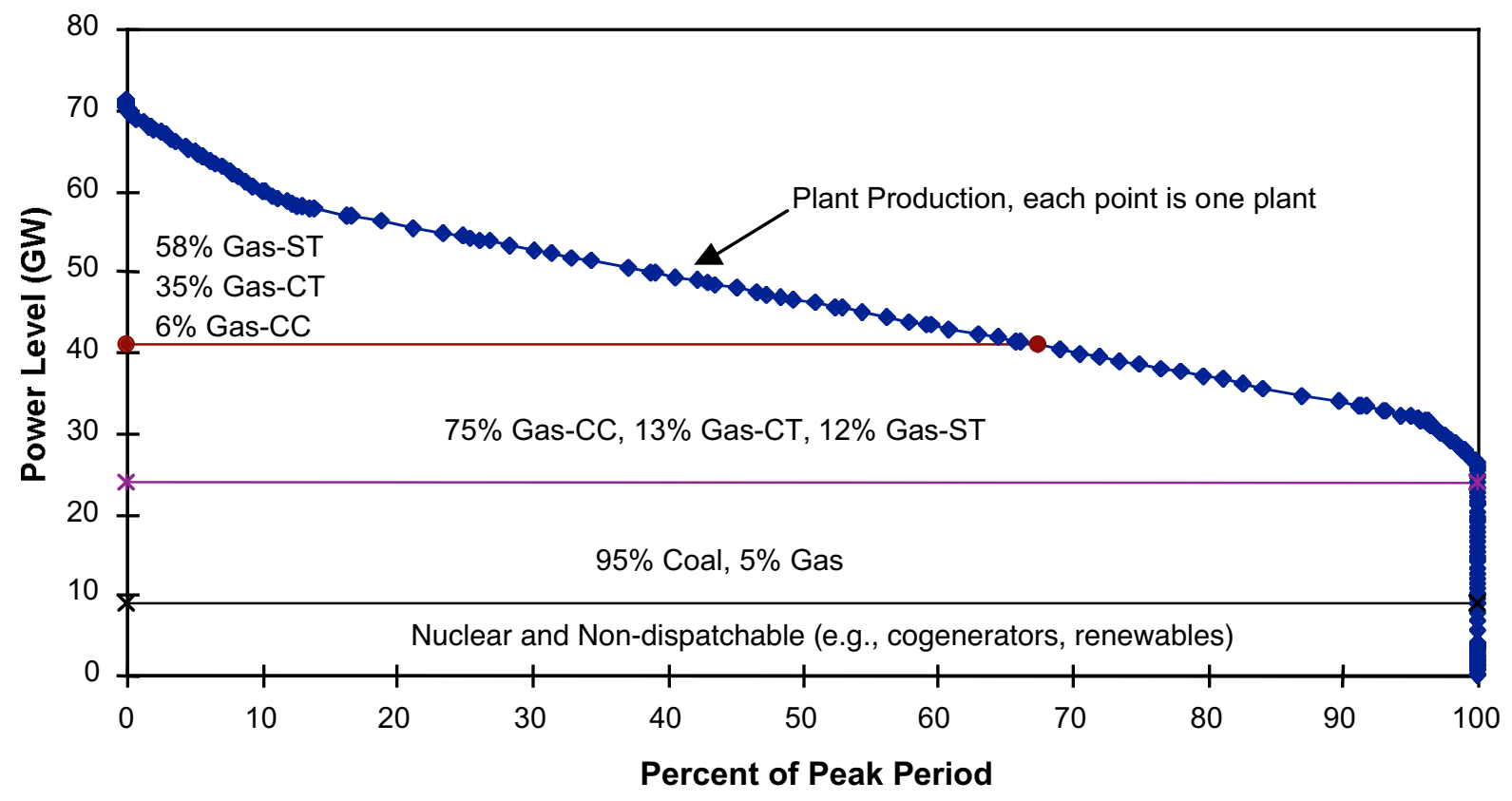


The plants that are along the top of the curve from $0 \%$ to $100 \%$ are the plants that are on the margin. If demand is reduced at any point in time, one of these plants will lower the percentage of time that they operate. Demand reductions at peak times (on the left side) will largely reduce gas-fired ST plants, while demand reductions at low power times will reduce CC plants mainly. If demand is reduced over the whole period (such as in the Baseload scenario), then all of the plants along the top will be reduced by some amount.

Interestingly, coal plants had low enough costs and were a small enough fraction of total capacity that they were essentially baseloaded, meaning that they were run whenever available. Because of their planned and forced outage rates, this ended up being less than $100 \%$; the amount varied depending on the availability for each of the 27 coal units modeled.

When DG reduces demand only in certain hours, such as the 8am-8pm weekday scenario, then the curve will be shaped differently. Some values at the peak will be lowered, as will some hours in the lower part of the curve, representing daytime loads during low-power days. As a consequence, the set of plants that are reduced will be a mixture of high-cost and medium cost plants, with different emissions characteristics.

\subsection{DISTRIBUTED GENERATION}

In addition to knowing the emissions reductions from the system plants, we must calculate the emissions from the DG. There are several sources available for DG cost and performance (RDC 2001, Nexus 2002, and Iannucci 2002). For this study, we used the parameters from Ianucci that lists technology data for DG in 2010 (Table 2). For this study we used the projected DG technology available in 2010 with cogeneration. Note that the Combustion Turbine- $6 \mathrm{~J}$ and two of the Natural Gas Engines do not meet proposed Texas $\mathrm{NO}_{\mathrm{x}}$ emissions standards of $0.14 \mathrm{lb}$ $\mathrm{NO}_{\mathrm{X}} / \mathrm{MWh}$, but are included to show the net emissions savings even if the DG standards were relaxed in 2012.

Table 2. Distributed Generation Technologies

\begin{tabular}{|c|c|c|c|c|}
\hline Technology & $\begin{array}{l}\text { Model/Type and NOx reduction } \\
\text { method }\end{array}$ & $\begin{array}{l}\text { Electrical } \\
\text { Efficiency }\end{array}$ & $\begin{array}{c}\mathrm{NO}_{\mathrm{x}} \\
\text { emissions, } \\
\text { lb/MWh }\end{array}$ & $\begin{array}{c}\mathrm{CO}_{2} \\
\text { emissions, } \\
\text { Ib/MWh }\end{array}$ \\
\hline Fuel Cell-12 & ONSI PC-25 / Phosphoric Acid & $45 \%$ & 0.0033 & 886 \\
\hline Fuel Cell-16 & Siemens / SOFC & $54 \%$ & 0.0055 & 739 \\
\hline Microturbine-6D & Capstone 60, DOE research target & $36 \%$ & 0.078 & 1,103 \\
\hline $\begin{array}{l}\text { Combustion } \\
\text { Turbine-6J }\end{array}$ & $\begin{array}{l}\text { Solar Mercury } 50 \text { Dry Low-emissions } \\
\text { combustion: } 9 \text { ppm NOx }\end{array}$ & $36 \%$ & 0.377 & 1,108 \\
\hline $\begin{array}{l}\text { Combustion } \\
\text { Turbine-8J }\end{array}$ & $\begin{array}{l}\text { Solar Mercury } 50 \text { Dry Low-NOx } \\
\text { combustion; SCR: } 2.5 \text { ppm NOx }\end{array}$ & $36 \%$ & 0.104 & 1,108 \\
\hline $\begin{array}{l}\text { Natural Gas Engine- } \\
\text { 9D }\end{array}$ & $\begin{array}{l}\text { Cummins QSK/QSV 98\% closed-loop } \\
\text { SCR + oxidation catalyst }\end{array}$ & $34 \%$ & 0.120 & 1,166 \\
\hline $\begin{array}{l}\text { Natural Gas En- } \\
\text { gine-Med NOx }\end{array}$ & $\begin{array}{l}\text { Cummins QSK/QSV with } \mathrm{NO}_{\times} \text {set to } \\
\text { current Texas standard }\end{array}$ & $34 \%$ & 0.470 & 1,166 \\
\hline $\begin{array}{l}\text { Natural Gas En- } \\
\text { gine-High NOx }\end{array}$ & $\begin{array}{l}\text { Cummins QSK/QSV with } \mathrm{NO}_{x} \text { set to } \\
\text { higher NOx value }\end{array}$ & $34 \%$ & 0.700 & 1,166 \\
\hline
\end{tabular}

Source: Iannucci 2002 
The electrical efficiency determines the amount of fuel input required for $100 \mathrm{MW}$ of output. This influences the amount of carbon that is emitted and the amount of thermal needs that can be provided by the technology if CHP is used. Cost factors are provided in the source as well, but analysis of cost factors are beyond the scope of this study.

If $\mathrm{CHP}$ is used so that steam generation from boilers is displaced, then the emissions of the boiler can be subtracted along with the displaced electricity generation. (We use boilers as an example, but the DG site's thermal needs could be in the form of hot water or some other thermal requirement.) Boiler emissions will vary depending on the age and Table 3. Heat exchanger efficiencies of CHP technologies

\begin{tabular}{|lccc|}
\hline \multicolumn{1}{|c}{ Technology } & $\begin{array}{c}\text { Heat } \\
\text { Exchanger } \\
\text { Efficiency }\end{array}$ & $\begin{array}{c}\text { Electrical } \\
\text { Efficiency }\end{array}$ & $\begin{array}{c}\text { Total } \\
\text { Efficiency }\end{array}$ \\
\hline Fuel Cell & $50 \%$ & $45 \%-54 \%$ & $73 \%-70 \%$ \\
Microturbine & $67 \%$ & $36 \%$ & $79 \%$ \\
Combustion Turbine & $62 \%$ & $36 \%$ & $76 \%$ \\
Natural Gas Engine & $52 \%$ & $34 \%$ & $68 \%$ \\
Non-CHP Boiler & $72 \%$ & - & - \\
\hline
\end{tabular}

Source: Calculated from product literature from ONSI, Unifin, Solar Turbines, and Fairbanks Morse. Electrical efficiencies from Table 2. type of boiler. If we assume they have similar characteristics to existing gas-fired steam electric generators, then we can find the average $\mathrm{NO}_{\mathrm{X}}$ emissions from the EIA and E-GRID data. The total $\mathrm{NO}_{\mathrm{X}}$ emissions for gas-fired steam plants are 100,000 tons and heat input is 870 TBtus. This gives an emission rate of $0.23 \mathrm{lb} \mathrm{NO}_{\mathrm{X}} / \mathrm{MBtu}$. Steam boilers are typically more efficient (or effective) in converting fuel input to heat output than CHP units and we will assume a thermal efficiency (or effectiveness) of the boiler of $72 \%$ (ratio of useful energy out to energy in), while the efficiency of the boiler portion of the CHP depends on the type of technology (Table 3). Combined, the electrical and thermal efficiency for the DG technologies when using CHP is between $68 \%$ and $79 \%$ [total efficiency $=$ electrical efficiency + thermal efficiency $\times(1-$ electrical efficiency)]. These values may appear low compared to other literature, but these values are based on the higher heating value of gas rather than lower heating value (which does not include recovery of the latent heat of vaporization in the input.) Using the lower heating value raises the apparent efficiency approximately $10 \%$. 


\section{RESULTS}

We ran the ORCED model using each of the three LDC's: with no DG, with $100 \mathrm{MW}$ of peaking power displaced by DG, and with 100 MW of baseload power displaced by DG. The differences in system operation reflect the displacement of marginal plant production over the year. Table 4 shows the key parameters of the displaced power. The total amount of power reflects the number of hours each type of DG ran, either 3132 hours or 8760 hours. Because the peaking DG generally ran when demands were higher, it displaced proportionally more gas-fired
Table 4. Key parameters of displaced system power

\begin{tabular}{|c|rc|}
\hline & $\begin{array}{c}\text { Peaking } \\
\text { DG }\end{array}$ & $\begin{array}{c}\text { Baseload } \\
\text { DG }\end{array}$ \\
\hline Displaced Energy, GWh & 313 & 876 \\
\hline Displaced Source & & \\
Gas ST & $59 \%$ & $36 \%$ \\
Gas CT & $26 \%$ & $21 \%$ \\
Gas CC & $15 \%$ & $43 \%$ \\
\hline Avg Efficiency & $33 \%$ & $37 \%$ \\
\hline $\mathrm{NO}_{\mathrm{x}}, \mathrm{lb} / \mathrm{MWh}$ & 1.39 & 1.14 \\
\hline $\mathrm{SO}_{2}, \mathrm{Ib} / \mathrm{MWh}$ & 0.00 & 0.00 \\
\hline $\mathrm{CO}_{2}, \mathrm{lb} / \mathrm{MWh}$ & 1,210 & 1,078 \\
\hline
\end{tabular}

ST production and less combined cycle production than the baseload DG. The efficiencies of the peaking displaced plants were lower, averaging 33\% efficient versus $37 \%$ efficient. This impacts the amount of primary energy required and therefore the carbon emissions. The peaking plants also had relatively higher $\mathrm{NO}_{\mathrm{X}}$ emissions, $1.39 \mathrm{lb} / \mathrm{MWh}$ versus $1.14 \mathrm{lb} / \mathrm{MWh}$ from the combination of plants displaced by the baseload DG. Since the displaced power was fueled by natural gas, there was essentially no $\mathrm{SO}_{2}$ reduction.

Table 5 and Figure 6 show the emissions generation of $\mathrm{CO}_{2}$ and $\mathrm{NO}_{\mathrm{x}}$ by the Combustion Turbine-8J listed in Table 2 as compared to the reductions from displaced power. In the baseload DG case, the $\mathrm{CO}_{2}$ emissions are actually higher for the microturbine (with an efficiency of 36\%) than the displaced power (with an average efficiency of 37\%.) The projected $\mathrm{NO}_{\mathrm{x}}$ emissions are much lower for the microturbine $(0.08 \mathrm{lb} / \mathrm{MWh})$ than the average emissions that are displaced so net emissions are negative.

Table 5. Net $\mathrm{CO}_{2}$ and $\mathrm{NO}_{\mathrm{x}}$ emissions from $100 \mathrm{MW}$ of Combustion Turbine-8J with and without CHP

\begin{tabular}{|l|l|rrrrr|}
\hline \multicolumn{2}{|c|}{} & Dist. Gen. & $\begin{array}{c}\text { Electric } \\
\text { System } \\
\text { Savings }\end{array}$ & $\begin{array}{c}\text { Net } \\
\text { Savings } \\
\text { w/o CHP }\end{array}$ & $\begin{array}{c}\text { Thermal } \\
\text { System } \\
\text { Savings }\end{array}$ & $\begin{array}{c}\text { Net } \\
\text { Savings wl } \\
\text { CHP }\end{array}$ \\
\hline $\mathrm{CO}_{2}$ Emissions, & Peaking DG & 173 & -189 & -16 & -48 & -64 \\
$\mathrm{kTons}$ & Baseload DG & 485 & -472 & 13 & -134 & -120 \\
\hline $\mathrm{NO}_{\mathrm{X}}$ Emissions, & Peaking DG & 16 & -217 & -201 & -188 & -389 \\
Tons & Baseload DG & 46 & -501 & -456 & -525 & -981 \\
\hline
\end{tabular}


Figure 6. Net $\mathrm{CO}_{2}$ and $\mathrm{NO}_{\mathrm{x}}$ emissions from $100 \mathrm{MW}$ of Combustion Turbine-8J w/o CHP

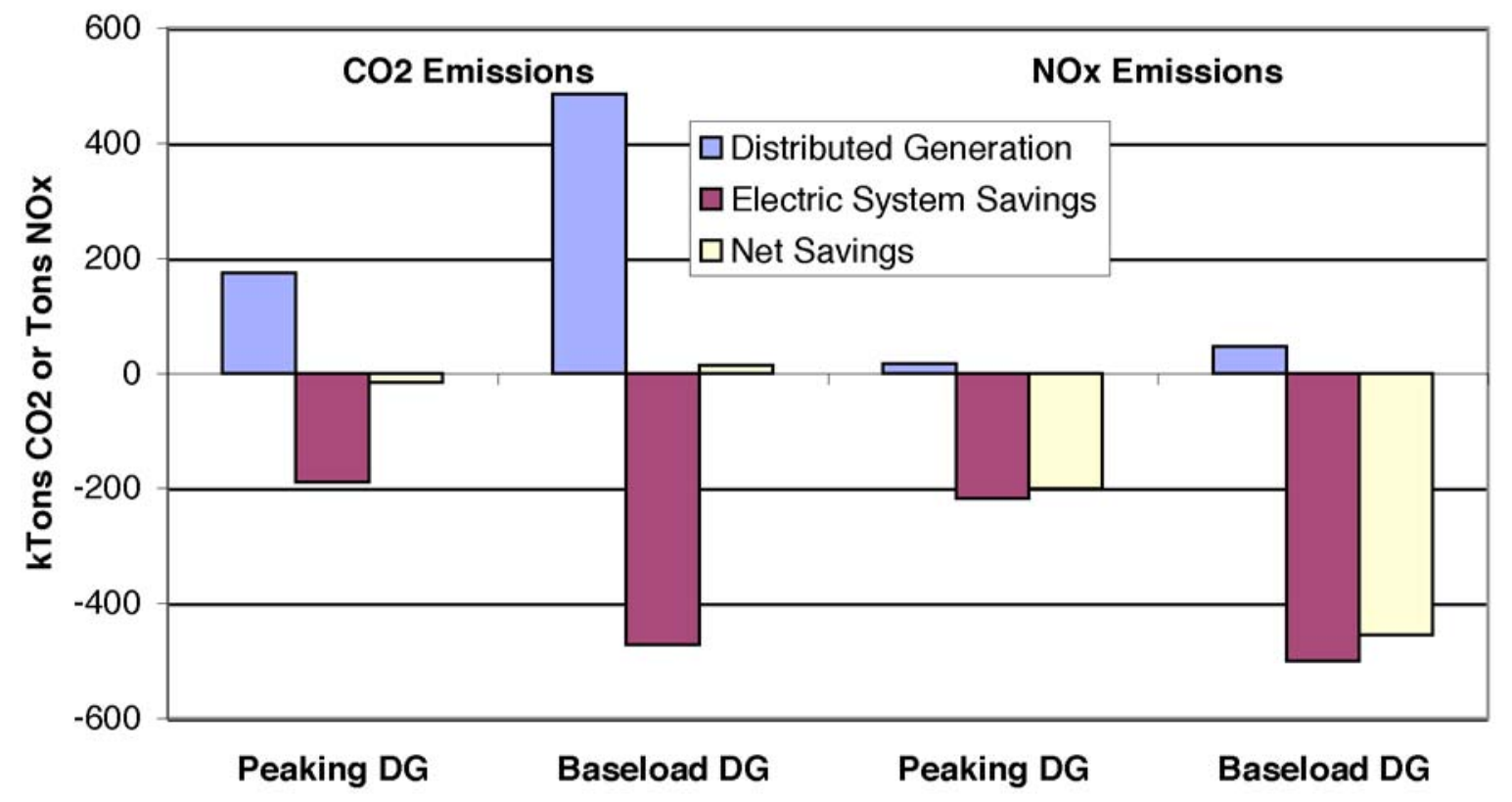

All of the DG technologies listed in Table 2 show significantly lower $\mathrm{NO}_{\mathrm{x}}$ emissions than the displaced power. Table 6 shows the net emissions for each technology when subtracting the system emissions.

Table 6. Net emissions from $100 \mathrm{MW}$ of different DG technologies w/o CHP

\begin{tabular}{|c|c|c|c|c|c|c|c|c|}
\hline \multirow[b]{2}{*}{$\begin{array}{c}\text { DG Technology } \\
\text { (Technology Ib NO } / \mathrm{MWh} \text { ) }\end{array}$} & \multicolumn{4}{|c|}{ Peaking DG } & \multicolumn{4}{|c|}{ Baseload DG } \\
\hline & kTon & $\begin{array}{l}\mathrm{O}_{2} \\
\mathrm{lb} / \mathrm{MWh}\end{array}$ & Ton & $\begin{array}{l}\mathrm{NO}_{\mathrm{x}} \\
\mathrm{Ib} / \mathrm{MWh}\end{array}$ & kTon & $\begin{array}{l}\mathrm{OO}_{2} \\
\mathrm{lb} / \mathrm{MWh}\end{array}$ & Ton & $\begin{array}{l}O_{x} \\
\mathrm{lb} / \mathrm{MWh}\end{array}$ \\
\hline Fuel Cell-12 (0.0033) & -51 & -324 & -217 & -1.39 & -84 & -191 & -500 & -1.14 \\
\hline Fuel Cell-16 (0.0055) & -74 & -471 & -217 & -1.38 & -148 & -339 & -499 & -1.14 \\
\hline Microturbine-6D (0.078) & -17 & -106 & -205 & -1.31 & 11 & 26 & -467 & -1.07 \\
\hline Combust Turbine-6J (0.377) & -16 & -102 & -158 & -1.01 & 13 & 30 & -336 & -0.77 \\
\hline Combust Turbine-8J (0.104) & -16 & -102 & -201 & -1.28 & 13 & 30 & -456 & -1.04 \\
\hline Nat Gas Engine-9D (0.12) & -7 & -44 & -199 & -1.27 & 39 & 89 & -449 & -1.02 \\
\hline Gas Engine-Med. $\mathrm{NO}_{\times}(0.47)$ & -7 & -44 & -144 & -0.92 & 39 & 89 & -295 & -0.67 \\
\hline Gas Engine-High $\mathrm{NO}_{x}(0.7)$ & -7 & -44 & -108 & -0.69 & 39 & 89 & -195 & -0.44 \\
\hline
\end{tabular}

The system reductions of 1.39 and $1.14 \mathrm{lb} / \mathrm{MWh}$ are offset by the emissions from the DG at its emission rate. Table 6 shows that with a peaking DG emissions rates of $0.7 \mathrm{lb} / \mathrm{MWh}$, there is a net savings of $0.69 \mathrm{lb} / \mathrm{MWh}$ overall. With lower emissions rates, the net savings are higher in a straight-line relationship, e.g., savings of $1.27 \mathrm{lb} / \mathrm{MWh}$ from the $\mathrm{DG}$ with an emission rate of $0.12 \mathrm{lb} / \mathrm{MWh}$. This is shown in the bottom two sets of points in Figure 7. 
Figure 7. System $\mathrm{NO}_{\mathrm{X}}$ savings as a function of the DG $\mathrm{NO}_{\mathrm{X}}$ emissions rate

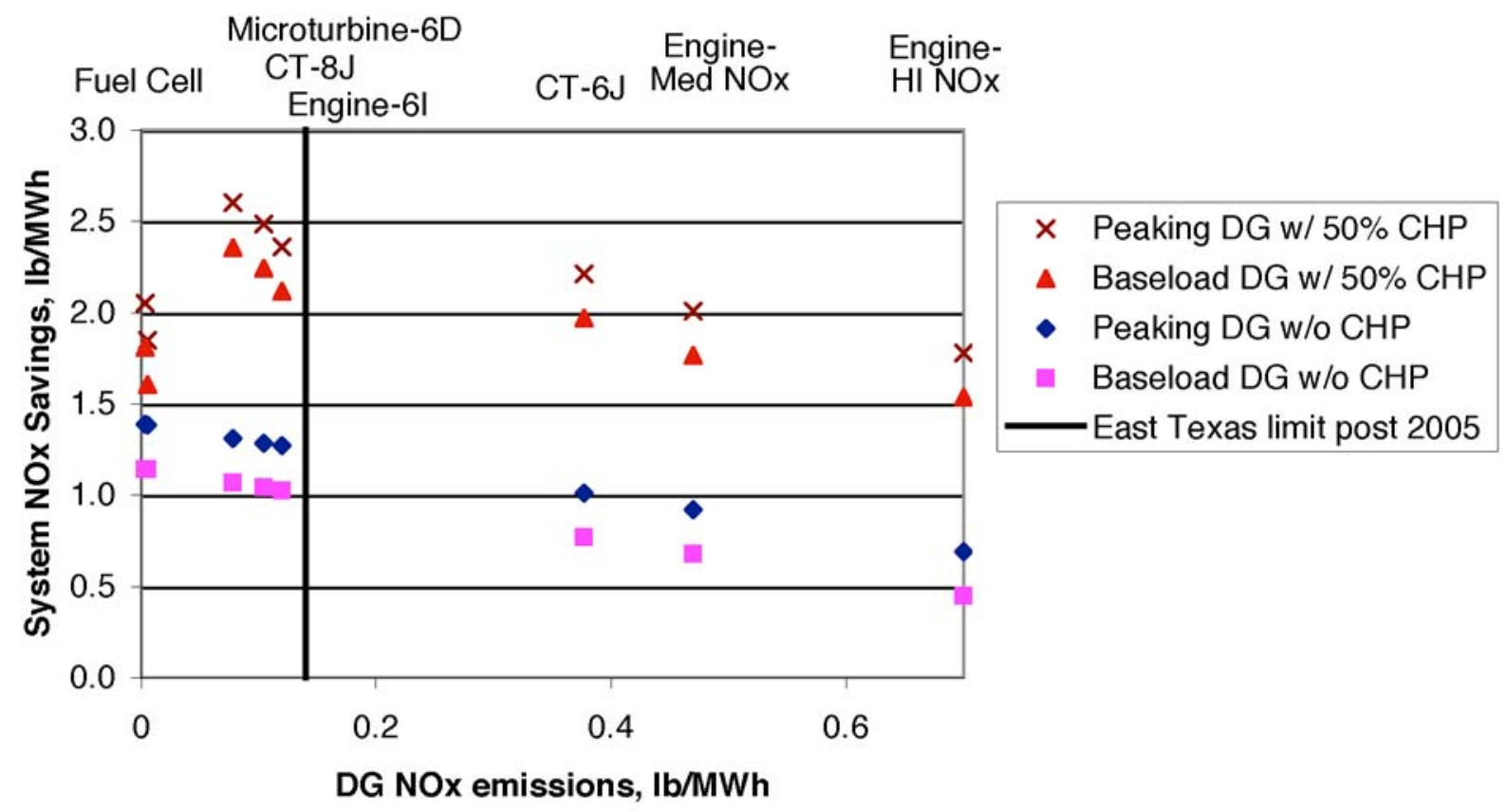

The use of the waste heat to displace steam generated from boilers will provide even greater savings, especially since the DG will see no increase in emissions over what it produced solely for electric generation. For example, $100 \mathrm{MW}$ of Combustion Turbine-8J running during peaking times would produce $313 \mathrm{GWh}$ and $1,900 \mathrm{GBtu}$ of exhaust heat. Assuming that $50 \%$ of the DG installations use CHP, with a $62 \%$ CHP heat exchanger efficiency compared to a $72 \%$ efficiency for the non-CHP boiler (Table 3), 817 GBtu of natural gas would be saved. This represents 48 kTon of $\mathrm{CO}_{2}$ and, using a $\mathrm{NO}_{\mathrm{x}}$ emission rate of $0.23 \mathrm{lb} / \mathrm{MBtu}$ for the boiler, 188 tons of $\mathrm{NO}_{\mathrm{x}}$ (Table 5 and Figure 8). When added to the power generation savings already achieved by the $\mathrm{DG}$, the total savings is $64 \mathrm{kTon}$ of $\mathrm{CO}_{2}$ and 389 tons of $\mathrm{NO}_{\mathrm{X}}$. Even greater amounts are saved with the baseload DG. Heat exchanger efficiencies are dependent mainly on the temperature of the exhaust, which depends on both the technology used and the efficiency of the electrical conversion. Fuel cells and engines typically have lower exhaust temperatures than turbines, and the energy is not as readily captured for other end-uses.

For all of the DG technologies listed, using the CHP parameters above, the emissions savings are shown in Table 7. Note that without CHP, the fuel cells reduced the $\mathrm{NO}_{\mathrm{x}}$ emissions the most, but their electrical efficiency is high and quality of exhaust low so that there is less exhaust heat available for CHP. This reduces the amount of boiler emissions displaced, so that the fuel cells have low net savings when CHP is used as compared to the other technologies. 
Figure 8. Net $\mathrm{CO}_{2}$ and $\mathrm{NO}_{\mathrm{x}}$ emissions from $100 \mathrm{MW}$ of Combustion Turbine-8J with 50\% CHP

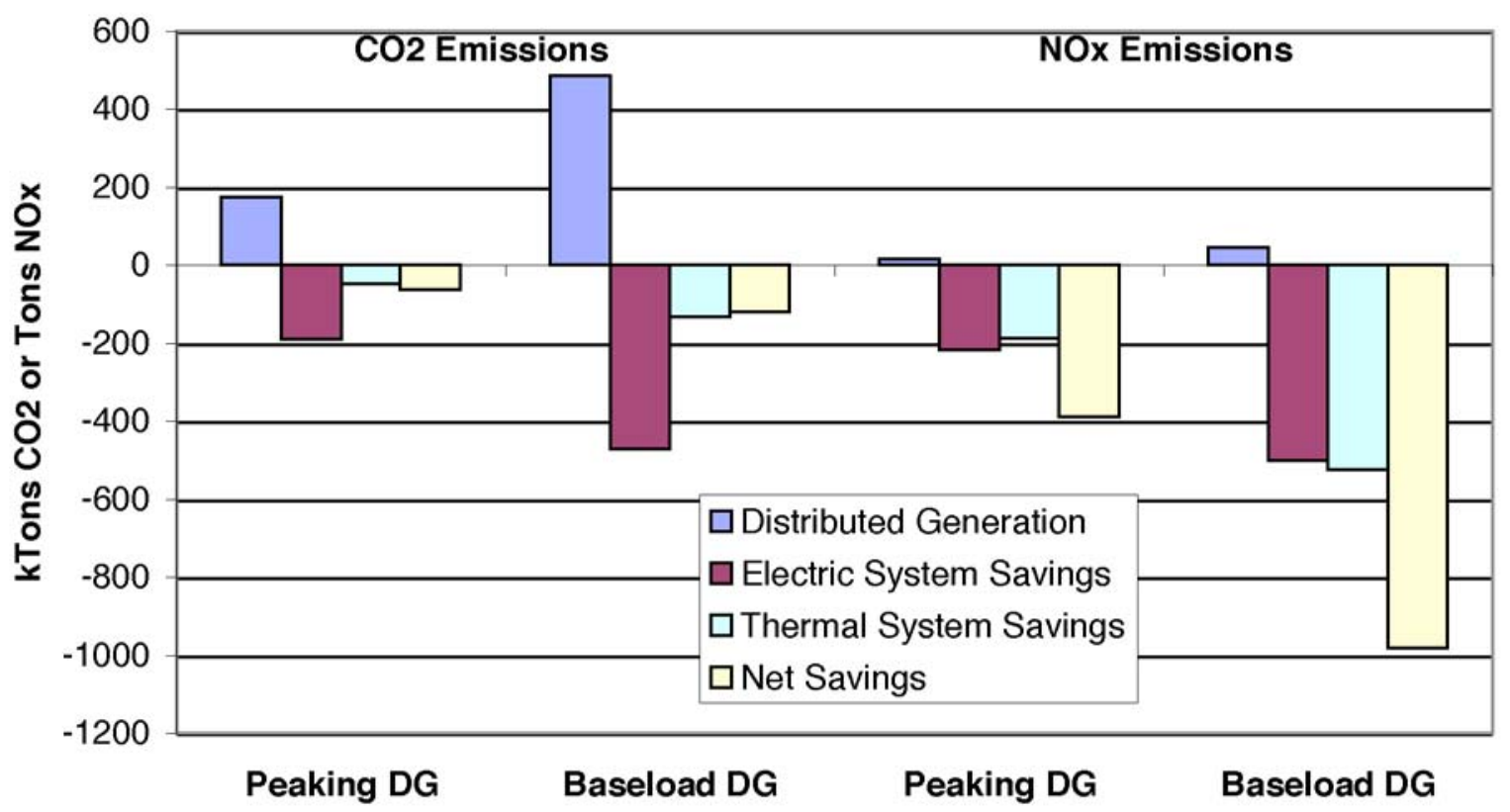

Table 7. Net emissions from $100 \mathrm{MW}$ of different DG technologies with $50 \%$ of DG being CHP

\begin{tabular}{|c|c|c|c|c|c|c|c|c|}
\hline \multirow{3}{*}{$\begin{array}{c}\text { Technology } \\
\text { (Technology Ib NOX/MWh) }\end{array}$} & \multicolumn{4}{|c|}{ Peaking DG } & \multicolumn{4}{|c|}{ Baseload DG } \\
\hline & \multicolumn{2}{|c|}{$\mathrm{CO}_{2}$} & \multicolumn{2}{|c|}{ NOx } & \multicolumn{2}{|c|}{$\mathrm{CO} 2$} & \multicolumn{2}{|c|}{ NOx } \\
\hline & kTon & lb/MWh & Ton & Ib/MWh & kTon & Ib/MWh & Ton & $\mathrm{Ib} / \mathrm{MWh}$ \\
\hline Fuel Cell-12 (0.0033) & -77 & -493 & -321 & -2.05 & -158 & -361 & -791 & -1.81 \\
\hline Fuel Cell-16 (0.0055) & -92 & -589 & -289 & -1.85 & -200 & -457 & -702 & -1.60 \\
\hline Microturbine-6D (0.078) & -68 & -434 & -407 & -2.60 & -132 & -302 & -1032 & -2.36 \\
\hline Combust Turbine-6J (0.377) & -64 & -407 & -346 & -2.21 & -120 & -275 & -862 & -1.97 \\
\hline Combust Turbine-8J (0.104) & -64 & -407 & -389 & -2.48 & -120 & -275 & -981 & -2.24 \\
\hline Nat Gas Engine-9D (0.12) & -50 & -321 & -369 & -2.36 & -82 & -188 & -926 & -2.11 \\
\hline Gas Engine-Med. $\mathrm{NO}_{x}, 0.47$ & -50 & -321 & -314 & -2.01 & -82 & -188 & -773 & -1.76 \\
\hline Gas Engine-High $\mathrm{NO}_{x}, 0.7$ & -50 & -321 & -278 & -1.78 & -82 & -188 & -672 & -1.53 \\
\hline
\end{tabular}

Table 7 provides the insight that if $50 \%$ of the DG installed by 2012 included CHP, emissions standards become a function not only of the cleanliness of the technology, but the electrical and heat exchanger efficiencies. This is apparent if we plot the system $\mathrm{NO}_{\mathrm{X}}$ savings as a function of the DG $\mathrm{NO}_{\mathrm{X}}$ emissions rate (Figure 7). While the electric-only system shows a simple linear relationship between the two, the plots for the systems with CHP show more variation. Fuel cells (on the far left side of the figure), because of their high electrical efficiencies and low exhaust temperature, do not show as large an improvement by adding CHP as do other technologies. With high electrical efficiency there is less exhaust energy to use, compounded by the low temperature which means that less of the exhaust energy can be captured for end-use. Microturbines, on the other hand, show high savings because of their combination of low emissions and high percentage of exhaust heat utilized (Table 3 ). 


\section{CONCLUSIONS}

Despite the retirement of some gas-fired steam units and the construction of many new gas combustion turbine and combined cycle units, the marginal emissions from the ERCOT system are quite high compared to projected DG emissions. As a consequence, additions of DG capacity even at emissions levels above the limit set by the state will reduce emissions in Texas from power generation. The marginal $\mathrm{NO}_{\mathrm{X}}$ emissions rate of the power system is 1.4 on peak and 1.1 lb $\mathrm{NO}_{\mathrm{X}} / \mathrm{MWh}$ baseload (Table 4), providing significant opportunity for emissions reductions utilizing DG (Figure 7). Using the DG exhaust heat for CHP is more important than using low emission technologies, since it eliminates further boiler emissions while adding none over what would be produced while generating electricity.

This analysis calculated the emissions change given a fixed electrical capacity within the state in 2012. On the other hand, if a large amount DG capacity is constructed then it becomes necessary to determine what central system capacity would be displaced. Either additional existing capacity would be retired, new capacity would not be built, or a mixture of both. Such decisions depend on the relative economics of the existing and new equipment rather than on the DG capacity. The choice made between retiring old or not building new could create significant differences from the results presented here.

These calculations concern the actual impact on air quality, and are not meant to argue for a change in regulatory standard-setting. As discussed throughout this paper, the net impact of DG on emissions is dependent on the characteristics of the rest of the system, which is beyond the control of the DG owner. This impact will change over time and will vary by location. Using such calculations for regulatory purposes would likely be contentious and cause great regulatory uncertainty for individual projects. However, the displacement of thermal energy production by using CHP is more clear-cut and computable since it means the replacement of thermal production at specific sites. Credit for these savings will improve the attractiveness of DG implementation.

Regardless of the regulatory consequences, even if just a fraction of the DG production displaces existing production versus new production, then emissions will decline. As shown in Table 5, the amount of emissions reduction from other sources can be over 20 times as much as the production from DG. Even if the displaced power were ten times cleaner or DG ten times worse, there would still be a net savings from DG. There is significant room for variation, but the conclusion remains the same in almost all cases - deployment of DG, especially in CHP applications, reduces the emissions of $\mathrm{NO}_{\mathrm{X}}$ and $\mathrm{CO}_{2}$. 


\section{REFERENCES}

EIA (Energy Information Administration) 2000a, National Energy Modeling System: An Overview 2000, DOE/EIA-0581 (2000), U.S. Department of Energy, Washington, DC, March. http://www.eia.doe.gov/oiaf/aeo/overview/introduction.html

EIA 2000b, Monthly Cost and Quality of Fuels for Electric Plants Data - 423 Data File 1999, U.S. Department of Energy, Washington, D.C. June.

ftp://ftp.eia.doe.gov/pub/electricity/f42399.exe

EIA 2001, Annual Energy Outlook 2002 with Projections to 2020, DOE/EIA-0383(2002), U.S. Department of Energy, Washington, D.C. December.

http://www.eia.doe.gov/oiaf/aeo/index.html

ftp://eia.doe.gov/pub/temp/aeo/aeo2002.exe

EPA (Environmental Protection Agency) 2001, E-GRID 2000PC, Version 2.0, Office of Atmospheric Programs, September.

http://www.epa.gov/airmarkets/egrid/

ERCOT (Electric Reliability Council of Texas) 2002,1999 FERC 714 Data, February. http://www.ercot.com/Participants/PeriodicReports/1999FERC714.zip

Hadley, S. and E. Hirst 1998, ORCED: A Model to Simulate the Operations and Costs of BulkPower Markets, ORNL/CON-464, Oak Ridge National Laboratory, Oak Ridge, TN, June. http://www.ornl.gov/orced/index.html

Iannucci, Joe, Susan Horgan, James Eyer, Lloyd Cibulka, 2002, Analysis of $\mathrm{NO}_{X}$ Emissions Limits for Distributed Generation in Texas, Distributed Utility Associates, Livermore, CA, May.

TNRCC (Texas Natural Resource Conservation Commission) 2001, Air Quality Standard Permit for Electric Generating Units, Air Permits Division, June.

Platts 2002, Powerdat Database, Platts, Inc., Boulder, Colo.

RDC (Resource Dynamics Corporation) 2001, Building Cooling, Heating, and Power (BCHP): A Market Assessment, Draft, September.

Southern Appalachian Mountain Initiative (SAMI) 2002, Final Technical Report, Draft, August, to be posted to http://www.saminet.org/ 